\title{
KARAKTERISTIK FONEM SEGMENTAL BAHASA MELAYU DIALEK AMBON
}

\author{
CHARACTERISTICS OF SEGMENTAL PHONEMES OF \\ AMBONESE MALAY
}

\author{
Erniati \\ Kantor Bahasa Maluku \\ Jalan Mutiara Nomor 3A, Kelurahan Rijali, Kecamatan Sirimau, Ambon \\ Pos-el: erniathyannekeisya@yahoo.co.id
}

\begin{abstract}
Abstrak
Bahasa Melayu Ambon adalah bahasa yang tergolong sebagai rumpun atau dialek dari bahasa Melayu standar yang dituturkan wilayah Provinsi Maluku yang mencakup Kota Ambon, Pulau Ambon, Pulau-pulau Lease yaitu Saparua, Haruku dan Nusa Laut serta Pulau Buano,Pulau Manipa, Pulau Kelang Pulau Seram serta dipakai pula sebagai bahasa perdagangan di Kei, Banda, Kepulauan watubela, Pulau Buru, Maluku Tenggara sampai Maluku Barat Daya. Bahasa Melayu dialek Ambon memiliki 2-2,5 juta penutur yang tersebar di seluruh Kepulauan Maluku. Bahasa Melayu dialek Ambon termasuk dalam rumpun bahasa Melayu Polinesia. Untuk melestarikan bahasa Melayu dialek Ambon ini diperlukan penelitian tetntang karakteristik fonem Bahasa Melayu dialek Ambon dan pendistribusiannya dalam kata. Penelitian ini bertujuan untuk mengetahui jumlah fonem bahasa Melayu dialek Ambon dan distribusinya dalam kata. Metode yang digunakan adalah metode kualitatif deskriptip. Hasil analisis menunjukaan bahwa fonem yang terdapat pada Bahasa Melayu dialek Ambon terdiri atas enam fonem vokal dan delapan belas fonem konsonan.
\end{abstract}

Kata Kunci: Fonologi, Fonetik, Fonem

\begin{abstract}
Ambonese Malay is classified as a dialect of the standard Malay language spoken in Maluku Province including Ambon City, Ambon Island, Lease islands of Saparua, Haruku and Nusa Laut and Buano Island, Manipa Island, Kelang island, Seram island. In addition, this language is also used as a trading language in Kei, Banda, Watubela Islands, Buru Island, Southeast Maluku to Southwest Maluku. Ambonese Malay has 2-2.5 million speakers spreading throughout the Maluku Islands. Ambonese Malay is included in the Malay Polynesian family. To preserve Ambonese Malay, it is necessary to study the characteristics of phonemes of Ambonese Malay and its distribution in word. This study aims to determine the number of Ambonese Malay's phonemes and its distribution in the word. The method used is descriptive qualitative method. The results show that the phoneme contained in Ambonese Malay consists of eighteen consonant phonemes.
\end{abstract}

Keywords: Phonology, Phonetics, Phonemes 


\section{Pendahuluan}

Bangsa Indonesia memiliki bahasa daerah yang sangat beragam. Bahasa daerah merupakan bagian integral dari kebudayaan daerah dan kebudayaan nasional. Dalam UUD 1945, Bab XV, Pasal 36 dituliskan bahwa bahasa negara ialah bahasa Indonesia. Pada penjelasannya disebutkan bahwa di daerah-daerah yang mempunyai bahasa sendiri, yang dipelihara oleh rakyatnya dengan baik (misalnya bahasa Jawa, Sunda, Madura, dan sebagainya) bahasabahasa itu akan dihormati dan dipelihara juga oleh negara. Bahasa-bahasa itu pun merupakan bagian dari kebudayaan Indonesia yang hidup.

Sebagai kebudayaan daerah, bahasa daerah memiliki tempat yang sangat penting di antara berbagai jenis kebudayaan daerah suatu kelompok etnis. Hal ini disebabkan bahasa daerah selain mengemban fungsi sebagai alat komunikasi antarmasyarakat daerah, juga berfungsi sebagai media pengembangan kebudayaan daerah. Oleh sebab itu, bahasa daerah perlu diteliti sebagai upaya untuk mengantisipasi kemungkinan kepunahannya. Hal ini bisa saja terjadi, sebab bahasa itu terus-menerus berubah. Jika perubahan-perubahan itu dibiarkan begitu saja, maka cepat atau lambat akan sampai ke titik kepunahan. Kehilangan atau punahnya bahasa berarti kehilangan sebuah kebudayaan nasional yang sangat tinggi nilainya.

Dari 132 bahasa daerah yang ada di Maluku, baru sebagian kecil yang sudah ditulis oleh peneliti Summer Institute of Linguistics (SIL) dalam aspek tertentu. Selain itu, terdapat beberapa penelitian bahasa daerah yang dilakukan oleh bangsa Indonesia sendiri, pada umumnya dilaksanakan oleh Badan Pengembangan dan Pembinaan Bahasa. Begitu pun dengan bahasa Melayu dialek Ambon. Bahasa Melayu dialek Ambon merupakan salah satu bahasa daerah yang dituturkan oleh masyarakat di Provinsi Maluku. Bahasa Melayu Ambon merupakan tergolong sebagai rumpun atau dialek dari bahasa Melayu standar yang dituturkan di wilayah Provinsi Maluku yang mencakup kota Ambon, pulau-Pulau Lease yaitu Saparua, Haruku dan Nusa Laut, serta Pulau Buano, Pulau Manipa, Pulau Kelang, Pulau Seram serta dipakai pula sebagai bahasa perdagangan di Kei, Banda, Kepulauan Watu Bela, Pulau Buru, Maluku Tenggara sampai Maluku Barat Daya.

Bahasa Melayu dialek Ambon berbeda dari Bahasa Melayu Ternate. Ini disebabkan karena bahasa Melayu Ambon mendapat banyak pengaruh dari bahasa Melayu Makassar, kemudian pada abad ke-16, Bangsa Portugis memasuki wilayah Maluku sehingga banyak kosa kata bahasa Portugis terserap ke dalam bahasa Melayu Ambon. Terakhir bangsa Belanda menjajah Maluku, sehingga serapan bahasa Belanda juga banyak yang terserap ke dalam bahasa Melayu Ambon. Bahasa Melayu Ambon ini memiliki penutur 245.020 juta penutur. Selain itu, sebagai bahasa sehari-hari masyarakat,bahasa Melayu Ambon ini juga dipakai sebagai bahasa pengantar di sekolah-sekolah, di gereja-gereja, dan juga terjemahan dalam alkitab.

Bahasa Melayu Ambon merupakan salah satu bahasa yang masih digunakan oleh masyarakat. Bahasa ini merupakan bahasa daerah yang memiliki kedudukan dan fungsi yang sama dengan bahasa daerah lain di Indonesia. Oleh sebab itu, patut mendapat prioritas dan perhatian yang sama dengan bahasa-bahasa daerah lain.

Mengacu pada uraian di atas maka dianggap perlu untuk meneliti struktur bahasa Melayu dialek Ambon yang dituturkan oleh masyarakat. Penelitian ini membatasi pada sistem fonem bahasa Melayu dialek Ambon. Dengan mengetahui karakteristik fonem bahasa 
Melayu Ambon tersebut, diharapkan upaya penanganan dalam rangka pembinaan bahasa Indonesia ragam lisan dapat diarahkan dengan lebih baik. Penelitian ini dilakukan untuk menginvetarisasi fonem-fonem bahasa Melayu dialek Ambon. Selain itu, penelitian ini juga dilakukan untuk melestarikan identitas bangsa. Kedudukan Bahasa Melayu dialek Ambon sebagai bahasa daerah merupakan salah satu unsur kebudayaan nasional yang dilindungi oleh negara. Dalam kedudukannya sebagai bahasa daerah, bahasa Melayu dialek Ambon berfungsi sebagai lambang kebanggan daerah, identitas daerah, dan alat perhubungan di dalam keluarga dan masyarakat daerah.

Berdasarkan latar belakang yang telah diuraikan di atas, masalah penelitian ini adalah bagaimanakah karakteristik fonem bahasa Melayu Ambon. Sedangkan tujuan penelitian ini adalah untuk mengetahui karakteristik fonem bahasa Melayu Ambon dan pendistribusian fonem tersebut dalam kata.

\section{Teori dan Metode}

\subsection{Teori}

Ada beberapa acuan yang mendukung kajian ini seperti yang dikemukakan oleh beberapa ahli antara lain antara lain, Samsuri (2005:23), Ramlan, Masnur Muchlis (2008:13), dan Nasir Thoir dan I Wayan Simpen (2001:45). Teori-teori tersebut digunakan sebagai acuan untuk menentukan fonem beserta alofonnya, pola suku kata, morfofonologi, serta ortografi bahasa Melayu dialek Ambon. Masnur Muchlish mengatakan bahwa dasar klasifikasi fonem segmental didasarkan berbagai macam kriteria, yaitu: (1) ada tidaknya gangguan maksudnya penyempitan dan penutupan yang dilakukan oleh alat-alat ucap atas arus udara dalam pembentukan fonem.
Dilihat ada atau tidaknya gangguan ketika fonem diucapkan, fonem dapat dikelompokkan menjadi dua yaitu fonem vokoid dan fonem kontoid.

mekanisme udara maksudnya bahwa dari mana datangnya udayra yang menggerakkan pita suara sebagai sumber fonem, (3) arah udara, maksudnya dilihat dari arah udara ketika fonem dihasilkan, (4) pita suara, maksudnya dilihat dari bergetar tidaknya pita suara yang dihasilkan, (5) lubang lewatan udara, maksudnya dilihat dari lewatan udara ketika fonem dihasilkan, (6) mekanisme artikulasi, maksudnya dengan mekanisme artikulasi adalah alat ucap mana yang bekerja atau bergerak ketika menghasilkan fonem bahasa. Sedangkan Nazhir Thoir dan I wayan Simpen mengatakan bahwa pada dasarnya bahwa fonem bahasa yang dihasilkan oleh alatalat ucap manuasia dapat dibedakan menjadi dua bagian. Baagian yang pertama merupakan fonem bahasa yang dapat dipecahkan atau dipisah-pisahkan dalam satu ruas. Sedangkan bagian kedua adalah fonem bahasa yang merupakan kebalikan dari fonem yang pertama, fonem ini tidak dapat dipisahkan menjadi beberapa segmen.

Samsuri (2005:45) memberikan petunjuk pokok-pokok pikiran yang disebut premis. Prinsip-prinsip yang yang dimaksud berupa pernyataan-pernyataan umum mengenai sifat-sifat fonem bahasa. Premis tersebut ialah 1) fonem bahasa mempunyai kecenderungan untuk dipengaruhi oleh lingkunannya dan 2) system fonem mempunyai kecenderungan bersifat simetris.

Selain premis tersebut, Samsuri (2005:46) juga mengemukakan dua hipotesisi kerja yang masing-masing disebut hipotesis kerja A dan hipotesis kerja B. hipotesis kerja itu sebagai berikut:

1) Fonem-fonem bahasa yang mirip sebagai fonetis harus digolongkan ke 
dalam kelas-kelas fonem atau fonemfonem yang berbeda, apabila terdapat pertentangan di dalam lingkungan yang sama atau yang mirip:

2) Fonem-fonem yang mirip secara fonetis dan terdapat dalam lingkungan yang komplementer harus dimasukkan ke dalam kelas-kelas fonem yang sama atau fonem yang sama.

Untuk melengkapi hipotetsis di atas digunakan pula prinsip kerja lingkungan analogus (analogus empironmen) (Multamia, 1997:26). Prinsip kerja ini menganjurkan jika ada fonem-fonem yang meragukan, dapat diteliti lebih lanjut apakah keduanya merupakan satu fonem atau fonem yang berbeda dengan cara membuat hipotesis dan menolak hipotesis. Ini berarti jika hipotesis diterima, maka kedua fonem tersebutmerupakan fonem yang sama, tetapi jika hipotesis ditolak, berarti kedua fonem yang mencurigakan itu adalah fonem yang berbeda.

Teori-teori merekalah yang dipergunakan sebagai tuntunan dalam menganalisis data secara keseluruhan.Selain teori di atas, untuk menentukan diftong, peneliti menggunakan dasar teori yang dikemukakan oleh Parera (2004....) . Teori dasar tersebut ialah sonoritas. Teori ini pada dasarnya menyarankan bahwa bila ada dua bunyi atau lebih yang tidak menunjukkan bunyi hamzah atau bunyi pelancar, maka harus diperhatikan dan dicatat apakah salah satu vokal berkurang sonoritasnya dan mengarah menjadi bunyi nonvokal. Apabila dalam urutan dua vokal itu ternyata salah satu vokal berkurang atau menurun sonoritasnya dan mengarah menjadi nonvokal, maka terjadilah diftong. Sedangkan untuk menentukan silabisasi, peneliti mendasari analisisnya pada pencatatan secara fonetis, fonemis, dan secara morfologi.

\subsection{Metode}

Metode yang digunakan dalam penelitian ini adalah metode deskriptif, yaitu penelitian yang dilakukan berdasarkan fakta yang ada atau fenomena yang secara empiris hidup pada penuturnya. Hasil yang diperoleh berupa perian bahasa yang dapat dikatakan sebagai paparan apa adanya (sudaryanto:1986:62 ). Menggambarkan tentang fonem-fonem bahasa Melayu Ambon secara lengkap . Untuk mendapatkan fonem bahasa secara sahih dalam suatu bahasa sangat ditentukan oleh sumber data dari bahasa yang bersangkutan. Karena dalam kajian fonologi yang diutamakan adalah data primer dan berusaka menghindari data sekunder. Sementara itu, teknik pengumpulan data yang digunakan adalah teknik studi pustaka, mengajukan pertanyaan berdasarkan kuesioner yang tersedia, dan catat-rekam. Data yang diperoleh dianalisis atas dasar analisis transkripsi secara fonetis maksudnya bahwa perekaman bunyi dalam bentuk lambang tulis atau lambang fonetis (fhonetic symbol) yang telah ditetapkan oleh The International Phoenetic Associations (IPA). Hasil transkripsi itulah yang kemudian diklasifikasikan berdasarkan jenis fonemnya. Langkah selanjutnya adalah mengklasifikasikan fonem tersebut sesuai kriteria klasifikasi fonem, kemudian mendistribusikan setiap fonem ke dalam kata. setelah itu menganalisis data sesuai dengan tujuan penelitian. Langkah terakhir adalah memaparkan hasil analisis dalam bentuk paparan deskripsi.

\section{Hasil dan Pembahasan \\ 3.1 Sistem Fonem Bahasa Melayu dialek Ambon}

\subsubsection{Fonem Vokal}

Vokal atau fonem vokal adalah bunyibunyi bahasa yang pada waktu pembentukannya udara keluar dari paruparu sedikit atau sama sekali tidak 
mendapat halangan. Cara pembentukan fonem vokal ada tiga macam sebagai berikut.

1. Berdasarkan naik turunnya lidah, ada fonem vokal atas, tengah, dan bawah.

2. Berdasarkan maju mundurnya lidah, ada fonem vokal depan, tengah, dan belakang.

3. Berdasarkan membundar tidaknya bibir, ada fonem vokal bundar dan tidak bundar.

Dari dasar pembentukan fonem vokal seperti itu, dalam bahasa Melayu Ambon ada 5 buah fonem vokal, yaitu :
1. Fonem vokal /i/, yang mempunyai ciri sebagai fonem atas, depan dan tidak bundar. 2. Fonem vokal /a/, yang mempunyai ciri sebagai fonem bawah, depan dan tidak bundar

3. Fonem vokal /e/, yang mempunyai ciri sebagai fonem vokal tengah dan tidak bundar.

4. Fonem vokal /u/, yang mempunyai ciri sebagai fonem vokal atas, belakang, bundar

5. Fonem vokal /o/, yang mempunyai ciri sebagai fonem vokal tengah, belakang, dan bundar.

Bagan 1

Fonem Vokal Bahasa Melayu Dialek Ambon

\begin{tabular}{|c|c|c|c|c|c|c|}
\multicolumn{2}{c|}{} & \multicolumn{2}{c|}{ Depan } & \multicolumn{2}{c|}{ Tengah } & \multicolumn{2}{c|}{ Belakang } \\
\cline { 2 - 7 } & TBL & BL & TBL & BL & TBL & BL \\
\hline \multirow{2}{*}{ Tinggi atas } & $\mathrm{i}$ & & & & & $\mathrm{u}$ \\
\hline \multirow{2}{*}{ Sedang $\begin{array}{c}\text { atas } \\
\text { bawah }\end{array}$} & & & & & & \\
\hline Bawah & & & & & & 0 \\
\hline
\end{tabular}

Keterangan: $\mathrm{TBL}=$ tak bulat

$\mathrm{BL}=$ bulat

Kelima fonem vokal Bahasa Melayu Ambon yang disebutkan di atas, akan dideskripsikan sebagai berikut:

1) Fonem Vokal [i]

Vocal depan tinggi, atas, tak bulat [i] dengan struktur tertutup terjadi pada posisi awal, tengah, dan akhir kata.

2) Fonem Vokal [u]

Vocal belakang, tinggi, atas, bulat [u] dengan struktur tertutup terjadi pada posisi awal, tengah,, dan akhir kata.

3) Fonem Vokal [e]

Vocal depan madya, bawah, tak bulat [e] dengan struktur semi terbuka terjadi pada posisi awal, tengah, dan akhir.

4) Fonem Vokal [o]

Vokal belakang, madya, bawah, bulat [o]dengan struktur semi terbuka, terjadi pada posisi awal, tengah, dan akhir.

5) Fonem Vokal [a]

Vokal tengah, rendah, tak bulat [a], dengan struktur terbuka, terjadi pada posisi awal, tengah, dan akhir.

\subsubsection{Fonem Konsonan}

Konsonan-konsonan Bahasa Melayu Ambon yang berhasil dideskripsikan yaitu: /p/, /b/, /ff/,t/, /d/, /c/, /j/, /k/, /g/, $/ ? /, / \mathrm{s} /, / \mathrm{m} /, / \mathrm{n} /, / \mathrm{y} /, / \mathrm{h} /, / \mathrm{l} /, / \mathrm{r} /, / \mathrm{w} /, / \mathrm{y} / \mathrm{dan}$ /G/. Jika dilihat dari daerah artikulasinya, maka fonem-fonem itu dapat diklasifikasikan menjadi enam kelompok, yaitu empat fonem bilabial, enam fonem lamino-alveolar, empat fonem laminopalatal, satu fonem glotal, tiga fonem dorso-velar, dan satu fonem labio-dental.

Jika fonem-fonem tersebut dilihat dari segi sifat ujaran, maka kedelapan 
belas fonem konsonan itu dapat dibagi lagi atas, delapan fonem letup (empat fonem bersuara dan empat fonem tansuara), tiga fonem sengau (nasal) bersuara, satu fonem getar bersuara, dua fonem geseran (frikatif), dua fonem hampiran (semi vokal), dan satu fonem sampingan (lateral). Agar lebih jelas, dapat dilihat tabel di bawah ini.

Tabel 2

Fonem Konsonan

\begin{tabular}{|c|c|c|c|c|c|c|c|c|}
\hline \multirow{2}{*}{$\begin{array}{c}\text { Cara } \\
\text { Artikulasi }\end{array}$} & \multicolumn{8}{|c|}{ Daerah Artikulasi } \\
\hline & $\begin{array}{c}\text { Bil } \\
\text { abi } \\
\text { al }\end{array}$ & $\begin{array}{c}\text { La } \\
\text { bio } \\
- \\
\text { den } \\
\text { tal }\end{array}$ & $\begin{array}{c}\text { Apik } \\
\text { o- } \\
\text { dent } \\
\text { al }\end{array}$ & $\begin{array}{c}\text { La } \\
\text { mi } \\
\text { no- } \\
\text { alv } \\
\text { eol } \\
\text { ar }\end{array}$ & $\begin{array}{c}\text { Lamino- } \\
\text { palatal }\end{array}$ & $\begin{array}{c}\text { Dorso- } \\
\text { velar }\end{array}$ & Faringal & Glotal \\
\hline Hambat & $\mathrm{pb}$ & & $t d$ & & & $\mathrm{~kg}$ & & $?$ \\
\hline Geseran & & $\mathrm{f}$ & $\mathrm{S}$ & & & & $\mathrm{h}$ & \\
\hline Paduan & & & & & $\begin{array}{l}c \\
j\end{array}$ & & & \\
\hline Sengauan & $\mathrm{M}$ & & $\mathrm{N}$ & & & G & & \\
\hline Getaran & & & $\mathrm{R}$ & & & & & \\
\hline Sampingan & & & $\mathrm{L}$ & & & & & \\
\hline Hampiran & W & & & & $\mathrm{Y}$ & & & \\
\hline
\end{tabular}

Fonem konsonan Bahasa Melayu Ambon dalam kata menempati posisi awal, tengah, dan akhir akan dideskripsikan sebagai berikut.

1) Fonem konsonan [p] adalah fonem konsonan hambat, letup, bilabial, tansuara, yang berartikulator aktif, bibir bawah, dan beratikulator pasif bibir atas, terjadi pada posisi awal, tengah dan akhir kata.

2) Fonem konsonan [b] adalah fonem konsonan bilabial, hambat implosive, bersuara. Pada dasarnya sama dengan bilabial hambat letup tansuara. Konsonan ini ditemukan pada posisi awal dan tengah kata.

3) Fonem konsonan [t] adalah fonem konsonan hambat, letup, apikodental, tak bersuara dengan articulator aktif ujung lidah dan artuikulator pasif gigi atas bagian dalam. Konsonan ini ditemukan pada posisi awal, tengah kata, dan akhir kata.

4) Fonem konsonan [d] adalah fonem konsonan ingresif glotalik (implosif0, letup afiko dental, bersuara, terjadi dengan articulator aktif, ujung lidah ditekankan rapat pada langit-langit keras tadi dilepaskan secara tiba-tiba, sehingga terjadi letupan udara (letupan masuk bukan sebaliknya). Konsonan ini ditemukan pada posisi awal dan tengah kata.

5) Fonem konsonan [k] adalah fonem konsonan hambat, letup, dorso-velar, tansuara dengan articulator aktif pangkal lidah dan articulator pasif langit-langit lunak (velum) terjadi karena pangkal lidah ditekankan rapat pada langit-langit. Langit-langit lunak tersebut beserta anak tekaknya dinaikkan sehingga hembusan suara dari paru-paru terhambat beberapa 
saat. Kemudian, tekanan pada langitlangit lunak itu dilepaskan secara tiba-tiba sehingga terjadi letupan dari rongga mulutdan pita suara dalam keadaan terbuka. Konsonan ini menempati posisi awal, tengah, dan akhir kata.

6) Fonem konsonan [g] adalah fonem konsonan dorso-velar, hambat, letup, bersuara, dengan articulator aktif pangkal lidah dan articulator pasif langit-langit lunak. Konsonan ini terjadi apabila pangkal lidah ditekankan rapat pada langit-langit lunak, sehingga udara yang keluar dari paru-paru terhambat beberapa saat. Konsonan ini berdistribusi pada awal dan tengah.

7) Fonem konsonan [c] adalah konsonan letup medio-palatal, tak bersuara . konsonan ini terjadi jika articulator aktifnya tengah lidah dan articulator pasifnya langit-langit keras. Fonem konsonan ini berdistribusi pada awal dan tengah kata.

8) Fonem konsonan [j] adalah konsonan lamino-palatal, bersuara. konsonan ini terjadi jika articulator aktifnya tengah lidah dan articulator pasifnya langit-langit keras. Fonem konsonan ini berdistribusi pada awal dan tengah kata.

9) Fonem konsonan [?] adalah konsonan hamzah. Konsonan ini terjadi dengan menekan rapat yang satu terhadap yang lain pada seluruh pita suara, langit-langit lunak beserta anak tekak ditekan ke atas sehingga arus udara terhambat beberapa saat. Distribusi fonem konsonan ini pada posisi tengah kata.

10) Fonem konsonan [m] adalah fonem konsonan hambat, nasal, bilabial, dengan articulator aktif bibir bawah dan articulator pasif bibir atas. Konsonan ini terjadi bila bibir bawah menekan rapat pada bibir atas; langit-langit lunak beserta anak tekak diturunkan, sehingga arus ujaran yang keluar dari paru-paru terhambat dan keluar melalui rongga hidung. Distribusi konsonan tersebut, pada posisi awal, tengah, dan akhir.

11) Fonem konsonan [s] adalah fonem konsonan frikatif, alveolar, tak bersuara dan lepas. Konsonan ini terjadi karena ujung lidah ditempelkan pada gusi, bagian lidah depan dinaikkan mendekati langitlangit keras. Posisi gigi agak dirapatkan sementara langit-langit lembut dinikkan sehingga jalan udara ke rongga hidung tertutup. Distribusi konsonan ini ditemukan pada posisi awal, tengah, dan pada akhir kata.

12) Fonem konsonan [n] adalah fonem konsonan hambat, nasal, apikoalveolar, yaitu konsonan yang beratikulator aktif ujung lidah dan articulator pasif gusi gigi atas. Konsonan ini terjadi karena ujung lidah ditekankan rapat pada gusi gigi atas; langit-langit lunak beserta jalan udara dari paru-paru melalui rongga mulut terhambat dan akhirnya keluar melalui rongga hidung. Distribusi konsonan tersebut ditemukan pada posisi awal, tengah, dan akhir kata.

13) Fonem konsonan semi vocal [y] adalah fonem semi vocal, laminopalatal, terjadi dengan articulator aktif lidah bagian tengah dan articulator pasif langit-langit keras. Atau dengan kata lain, lidah bagian tengah dinaikkan mendekati langitlangit keras tetapi tidak rapat. Demikian juga, dengan langit-langit lunak beserta anak tekakdinaikkan sehingga udara tidak keluar melalui rongga hidung, melainkan melalui rongga mulut dengan sedikit terhambat. Semi vocal ini menempati posisi awal dan tengah.

14) Fonem konsonan [h] adalah fonem konsonan yang merupakan konsonan 
glottal,geser, bersuara dan lepas. Proses terjadinya fonem ini, udara dapat keluar sebagai geseran melalui glotis yang terbuka lebar, kemudian udara itu keluar melalui mulut dan selaput suara tidak bergetar. Distribusi konsonan ini dapat ditemukan posisi awal dan tengah kata.

15) Fonem konsonan [f] adalah konsonan yang merupakanhasil dengan mempertemukan gigi atas sebagai titik artikulasi dan bibir bawah sebagai articulator. Distribusi konsonan ini dapat ditemukan pada posisi awal, tengah dan akhir.

\subsection{Fonem Segmental Bahasa Melayu Ambon.}

Berdasarkan analisis data, fonem-fonem segmental bahasa Melayu Ambon, memiliki lima fonem vokal dan sembilan belas fonem konsonan. Vokal-vokal tersebut, yaitu /i/, /u/, /e/, /o/, dan /a/. Kelima vokal ini memiliki ciri artikulatoris tersendiri. Misalnya, jika ditinjau dari segi bentuk bibir ketika melafalkannya, maka vokal-vokal tersebut terdiri atas tiga vokal tak bulat dan dua vokal bulat. Jika ditinjau dari segi naik turunnya lidah, maka vokalvokal tersebut diklasifikasikan dalam tiga kategori, yaitu dua vokal tinggi, dua vokal madya (sedang), dan satu vokal rendah. Sedangkan jika ditinjau dari bagian lidah yang bergerak, maka vokalvokal tersebut terdiri dari dua vokal depan, satu vokal tengah, dan dua vokal belakang. Sedangkan fonem konsonan Bahasa Melayu Ambon yang berhasil dideskripsikan yaitu: /p/,/b/, /d/, /g/, /h/, $/ \mathrm{j} /, / \mathrm{k} /, / \mathrm{l} /, / \mathrm{f} /, / \mathrm{m} /, / \mathrm{n} /, / \mathrm{r} /, / \mathrm{s} /, / \mathrm{t} /, / \mathrm{c} /, / \mathrm{w} /$, /y/, /y/, /dan /?/. Jika dilihat dari daerah artikulasinya, maka fonem-fonem itu dapat diklasifikasikan menjadi enam kelompok, yaitu empat fonem bilabial, enam fonem afiko-dental, tiga fonem lamino-palatal, satu fonem glotal, tiga fonem dorso-velar, dan satu fonem faringal.

Jika fonem-fonem tersebut dilihat dari segi sifat ujaran, maka ke delapan belas fonem konsonan itu dapat dibagi lagi atas, delapan fonem letup (empat fonem bersuara dan empat fonem tansuara), tiga fonem sengau (nasal) bersuara, satu fonem getar bersuara, dua fonem geseran (frikatif), dua fonem hampiran (semi vokal), dan satu fonem sampingan (lateral). Agar lebih jelas, dapat dilihat tabel di bawah ini.

Untuk membuktikan pernyataan di atas, berikut ini dikemukakan contoh melalui kontras vokal dan konsonan Bahasa Melayu Ambon

\subsection{Kontras Fonem Vokal}

1. Kontras Vokal /a/ dengan /i/

Kedua fonem vokal di atas merupakan dua buah fonem yang bebeda. Hal ini dapat dilihat pada contoh berikut.

$\begin{array}{ll}\text { /da/ } & \text { 'selamat' } \\ \text { /di/ } & \text { 'lihat' } \\ \text { /ada/ } & \text { 'ada' } \\ \text { /adi/ } & \text { 'adik' }\end{array}$

\section{Kontras Vokal /a/ dan /o/}

Kedua fonem vokal di atas merupakan dua buah vonem yang berbeda. Hal ini dapat dilihat pada contoh berikut.

$\begin{array}{ll}\text { /ada/ } & \text { 'ada' } \\ \text { /ado/ } & \text { 'pernyataan kesal' } \\ \text { /jaga/ } & \text { 'dahan kayu' } \\ \text { /jago/ } & \text { 'hebat' }\end{array}$

\section{Kontras Vokal /o/ dan /i/}

Kedua fonem vocal di atas merupakan dua buah vonem yang berbeda. Hal ini dapat dilihat pada contoh berikut.
$/ \mathrm{d} \mathbf{0} /$
'sebentar'
/di/
'lihat'

\section{Kontras Vokal /u/ dan /i/}

Kedua fonem vocal di atas merupakan dua buah vonem yang berbeda. Hal ini dapat dilihat pada contoh berikut. 
/adu/ 'kata seru yang [amato] 'selamat jalan'

menyatakan sakit atau gembira'

ladi/ 'adik'

\section{Kontras Vokal/o/ dan /u/}

Kedua fonem vocal di atas merupakan dua buah vonem yang berbeda. Hal ini dapat dilihat pada contoh berikut.

/ado/ 'kata yang menyatakan

kesal'

/adu/ 'kata seru yang

menyatakan gembira atau sakit'

Berdasarkan analisis data, selain kontras vokal, juga ditemukan fonem vokal yang mengalami perubahan sesuai dengan lingkungannya. Dengan kata lain, fonem itu dapat dipengaruhi oleh fonem yang sebelumnya atau sesudahnya sehingga dapat terjadi pergeseran fonetis. Pergeseran fonetis tersebut disebut alofon dari fonem yang bersangkutan. Fonem vokal yang memiliki alofon adalah sebagai berikut:

\section{Vokal /e/}

Fonem /e/ memiliki variasi atau alofon [E], dan [e]. Variasi tersebut terjadi sesuai dengan lingkungannya masingmasing, yaitu:

[€], terjadi pada suku terbuka yang mendapat tekanan;

[e], terjadi pada tempat yang lain.

Contoh:

[gEpE] 'mepet'

[aer] 'air'

\section{Vokal /o/}

Fonem /o/ memiliki variasi atau alofon [O], dan [o]. Variasi-variasi tersebut terjadi sesuai dengan lingkungannya masing-masing, yakni:

[O], terjadi pada suku terbuka yang mendapat tekanan;

[o], terjadi pada tempat yang lain.

Contoh:

[adO] 'kata yang menyatakan

\subsection{Distribusi Fonem}

\subsubsection{Distribusi Fonem Vokal}

Fonem vokal Bahasa Melayu Ambon berdistribusi lengkap artinya fonem vokal bahasa Melayu Ambon tersebut hadir pada awal, tengah, dan akhir kata. Untuk mempertegas uraian tersebut, berikut ini deskripsi fonem vokal dalam kata.

\section{Vokal /a/}

Contoh:

$\begin{array}{lll}\text { awal } & {[\text { abis }]} & \text { 'habis' } \\ & {[\text { aer] }} & \text { 'air' } \\ \text { tengah } & {[\text { apaker }]} & \text { 'rusak' } \\ & {[\text { atakereG] }} & \text { 'menyerbu' } \\ \text { akhir } & {[\text { arika] }} & \text { 'cekatan' } \\ & {[\text { ampa }]} & \text { 'empat' }\end{array}$

2. Vokal /i/

Contoh:

awal [idoG] 'hidung'

[ikaG] 'ikan'

tengah [baiko] 'mengikuti'

[saika] 'seikat'

akhir [jeksi] 'suntik'

[kamiri] 'kemiri'

3. Vokal /u/

Contoh:

awal [usi] 'kakak perempuan'

[upiG] 'kecil sekali'

tengah [kalamumur] 'kotembe'

[ubuG] 'sambung'

akhir [upu] 'ayah'

[unju] 'tunjuk'

4. Vokal /e/

Contoh:

$\begin{array}{lll}\text { awal } & {[\text { eja] }} & \text { 'olok' } \\ & {[\text { ewaG }]} & \begin{array}{l}\text { 'hutan lebat' } \\ \text { tengah }\end{array} \\ & {[\text { eleG] }} & \text { 'segan' } \\ & {[\text { eksameG] }} & \text { 'ujian' } \\ \text { akhir } & {[\text { gale }]} & \text { 'cabut' } \\ & {[\text { eje }]} & \text { 'olok' }\end{array}$

5. Vokal /o/

Contoh: 


\begin{tabular}{|c|c|c|}
\hline awal & [oleG] & 'miring' \\
\hline & [oma] & 'nona' \\
\hline tengah & [kombali] & 'kembali' \\
\hline & [kolaG] & 'lobang' \\
\hline akhir & [iko] & 'usir \\
\hline
\end{tabular}

[konco] 'teman'

Untuk mempertegas uraian di atas, berikut ini tabel distribusi vokal.

Tabel 2

Distribusi Vokal

\begin{tabular}{|c|c|c|c|}
\hline \multirow{2}{*}{ Vokal } & \multicolumn{3}{|c|}{ Distribusi Vokal dalam Kata } \\
\cline { 2 - 4 } & Awal & Tengah & Akhir \\
\hline I & + & + & + \\
\hline E & + & + & + \\
\hline O & + & + & + \\
\hline A & + & + & + \\
\hline
\end{tabular}

Keterangan:

$+=$ terdapat pada distribusi tersebut

\subsubsection{Distribusi Fonem Konsonan}

Distribusi fonem konsonan Bahasa Melayu Ambon dalam kata menempati posisi awal, tengah, dan akhir. Berikut ini deskripsi fonem konsonan dalam kata.

\subsubsection{Fonem konsonan yang berdistribusi lengkap (awal, tengah, dan akhir kata)}

1. Konsonan $/ \mathrm{m} /$

Contoh:

$\begin{array}{ll}\text { awal } & {[\mathrm{mar}]} \\ & {[\mathrm{ma}]} \\ \text { tengah } & {[\text { mamboro }]} \\ & {[\text { mampos }]} \\ \text { akhir } & {[\mathrm{om}]}\end{array}$

2. Konsonan /p/

Contoh:

$\begin{array}{lll}\text { awal } & \begin{array}{l}\text { [padede] } \\ {[\text { pakansi] }}\end{array} & \begin{array}{l}\text { 'cengeng' } \\ \text { 'libur' }\end{array} \\ \text { tengah } & {[\text { tapake }]} & \text { 'terkenal' } \\ & {[\text { bapake] }} & \text { 'memakai' } \\ \text { akhir } & {[\text { hidop] }} & \text { 'hidup' }\end{array}$

3. Konsonan $/ \mathrm{n} /$

Contoh:

$\begin{array}{lll}\text { awal } & {[\text { nai }]} & \text { 'naik' } \\ \text { tengah } & {[\text { nanaku }]} & \text { 'pedoman' } \\ & {[\text { nanalu }]} & \text { 'selalu' } \\ & {[\text { nonai }]} & \text { 'umpan' }\end{array}$

akhir [non] 'sebutan untuk wanita'

$$
\text { [sein] 'isyarat/kode’ }
$$

4. Konsonan /k/

Contoh:

awal [kalsang]

[kaluyu]

'celana'

'ikan hiu'

tengah [keku]

'menjunjung'

[kakarlak] 'kecoa'

akhir [sak]

'saku'

5. Konsonan $/ \mathrm{r} /$

Contoh:

awal [rai] 'tebak'

[ruk-ruk] 'suka marah'

tengah [rarobaG] 'santan yang tidak jadi minyak'

[saraGke] 'seringkali'

akhir [salawar] 'sial'

[samemer] 'sangat besar'

6. Konsonan /1/

Contoh:

awal [lai] 'lagi'

[laju] 'cepat'

tengah [kele] 'gandeng'

[ela] 'ampas sagu'

akhir [embal] 'kue sagu' 


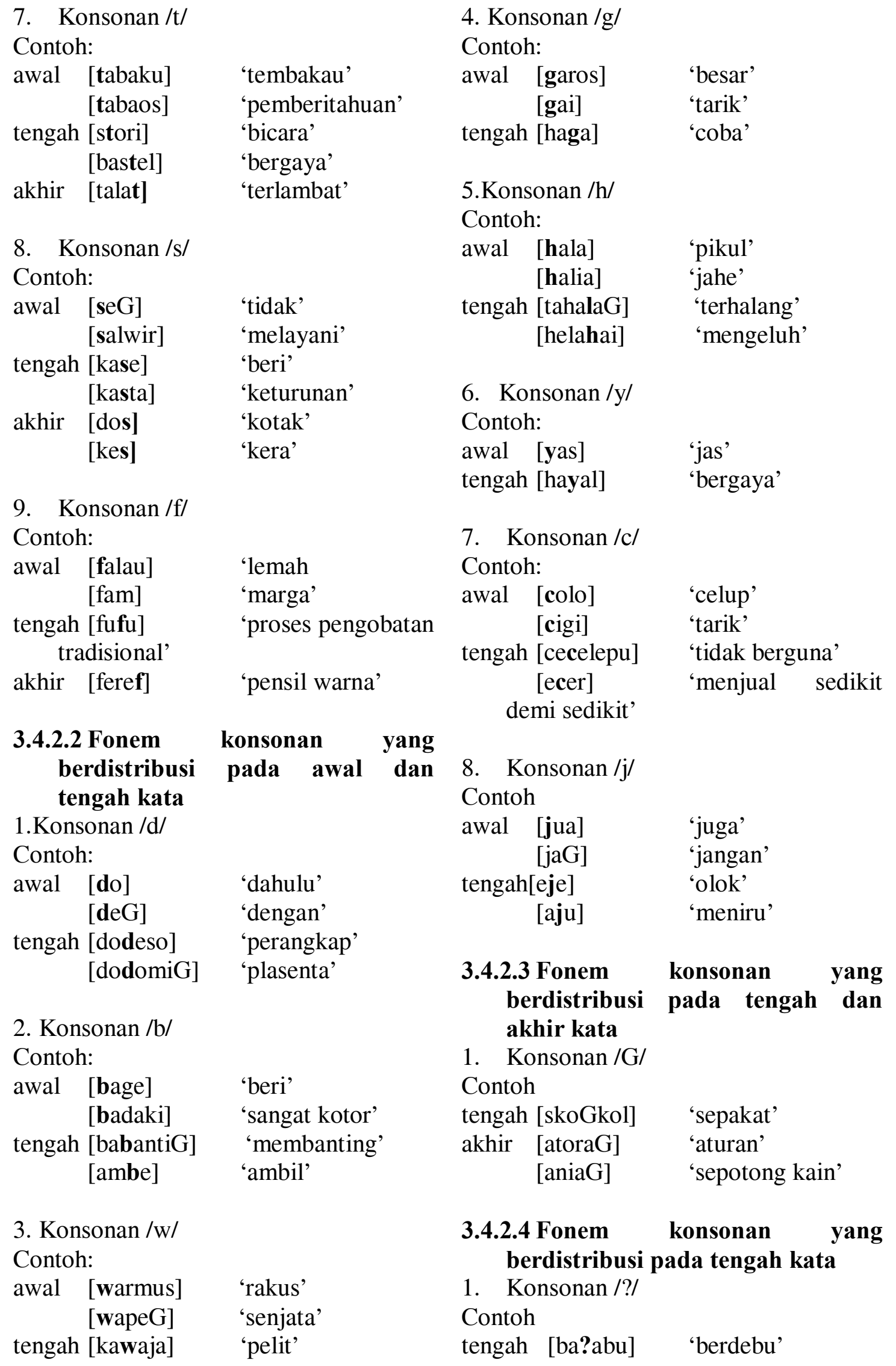


tumbuh'

[a?oG] 'bekas kebun yang

Tabel 3

Distribusi Fonem Konsonan dalam Kata

\begin{tabular}{|c|c|c|c|}
\hline Konsonan & Awal Kata & Tengah Kata & Akhir Kata \\
\hline P & + & + & + \\
\hline M & + & + & + \\
\hline K & + & + & + \\
\hline R & + & + & + \\
\hline L & + & + & + \\
\hline T & + & + & + \\
\hline S & + & + & + \\
\hline F & + & + & + \\
\hline D & + & + & - \\
\hline B & + & + & - \\
\hline G & + & + & - \\
\hline H & + & + & - \\
\hline Y & + & + & - \\
\hline C & + & + & - \\
\hline J & + & + & - \\
\hline$?$ & + & + & - \\
\hline G & - & + & - \\
\hline
\end{tabular}

Keterangan:

$+\quad=$ terjadi pada distribusi tersebut

- $\quad=$ = tidak terjadi pada distribusi tersebut

\section{Simpulan}

Penelitian ini menghasilkan beberapa kesimpulan, terutama mengenai hasil fonemisasi, yaitu bahasa Melayu dialek Ambon memiliki dua puluh tiga fonem segmental, yang terdiri dari sembilan belas fonem konsonan dan lima fonem vokal.

Konsonan-konsonan bahasa Melayu Ambon yang berhasil dideskripsikan yaitu: /p//ff/ /m/, /n/, /r/, /k/, /r/, /l/, /t/, /s/, $/ \mathrm{d} /, / \mathrm{b} /, / \mathrm{w} /, / \mathrm{g} /, / \mathrm{h} /, / \mathrm{y} /, / \mathrm{c} /, \mathrm{j} /, /, / /$, dan $/ \mathrm{G} /$. Sedangkan fonem-fonem vokal terdiri dari vokal, depan, tinggi, tak bulat /i/; vokal, belakang, tinggi, bulat /u/; vokal, depan, sedang, tak bulat /e/, vokal, belakang, sedang, bulat /o/, dan vokal, rendah, tengah $/ \mathrm{a} /$.

\section{Daftar Pustaka}

Daniel, Jos Parera. 1987. Pengantar Linguistik Umum. Ende Flores: Nusa Indah.

Dharmojo, dkk. 1994. Fonologi Bahasa Ekagi. Jakarta: Pusat Pembinaan dan Pengembangan Bahasa.

Hadibrata, Halimi. 2007. Analisis Kontrastif Fonologi dan Morfologi Bahasa Indonesia dengan Bahasa Dayak Rentenuukng di Kutai Barat, Kalimantan Timur. Jakarta: Pusat Pembinaan dan Pengembangan Bahasa.

Iper, Dunis, dkk. 2000. Fonologi Bahasa Maanyan. Jakarta: Pusat Pembinaan dan Pengembangan Bahasa.

Kamus Besar Bahasa Indonesia. 2005. Jakarta: Departemen Pendidikan Nasional. 
Kridalaksana, Hartimurti. 1987. Kamus Linguistik. Gramedia: Jakarta.

Lapoliwa, Hans. 1980. Analisis Fonologi. Jakarta: Pusat Pembinaan dan Pengembangan Bahasa.

Lauder, Multamia RMT. 1997. Pedoman Pengenalan dan Penulisan Bunyi. Jakarta: Pusat Pembinaan dan Pengembangan Bahasa.

Marsono. 1986. Fonetik. Yogyakarta: Gadjah Mada University Press.

Pike, Kenneth L. 1968. Phonemic. Arlington: Summer Institute of Linguistic.

Purba TH., dkk. 2002. Fonologi Bahasa Amungkal. Jakarta: Pusat Bahasa.
Ruswan, dkk. 2000. Fonologi Bahasa Bonai. Jakarta: Pusat Pembinaan dan Pengembangan Bahasa.

Samsuri. 1985. Analisis Bahasa. Jakarta: Erlangga.

Sanjoko, Yohanis, dkk. 2008. Fonologi Bahasa Orya. Jayapura: Balai Bahasa Jayapura.

Sudaryanto. 1986. Metode Linguistik. Yogyakarta: Gadjah Mada University Press.

Sulisusiawan, Ahadi, dkk. 1999. Fonologi Bahasa Badayuh. Jakarta: Pusat Pembinaan dan Pengembangan Bahasa. 